\title{
A case of cerebral abscess due to Cladophialophora bantiana
}

\author{
Atul Aher ${ }^{1}$, Vichal Rastogi \\ ${ }^{1}$ Department of Microbiology, Peoples College of Medical Science E Research Centre, Bhopal, India \\ 2 Department of Microbiology, School of Medical Sciences $\mathcal{E}$ Research Centre, Greater Noida, India
}

\begin{abstract}
Cladophialophora bantiana is a dematiaceous fungus which belongs to family Phaeohyphomycetes. It is primarily a neurotropic fungus causing central nervous system infection. We report a case of a brain abscess in frontoparietal region in a diabetic patient caused by C. bantiana. Diagnosis was made based on the microscopy and culture of the pus material obtained after craniotomy. The patient died despite of surgical intervention and appropriate antifungal therapy. J Microbiol Infect Dis 2012;2(4): 171-173
\end{abstract}

Key words: Brain abscess, Cladophialophora bantiana, Phaeohyphomycoses

\section{Cladophialophora bantiana ile olan bir beyin absesi olgusu}

\section{ÖZET}

Cladophialophora bantiana Phaeohyphomycetes ailesine bağlı siyah renkli bir mantardır. Merkezi sinir sistemi enfeksiyonuna yol açan nörotropik bir mantardır. Diyabetik bir hastanın frontoparital bölgesinde C. bantiana ile gelişen bir beyin apsesini bildirdik. Tanl; mikroskopi ve kraniyotomi sonrası alınan apse materyal kültüründen konuldu. Hasta cerrahi müdahale ve uygun antifungal tedaviye rağmen öldü.

Anahtar kelimeler: Beyin absesi, Cladophialophora bantiana, Phaeohyphomycoses

\section{INTRODUCTION}

Phaeohyphomycosis is a heterogeneous group of mycotic infections caused by dematiaceous fungi. They have ability to cause subcutaneous and systemic infections. The invasive and systemic phaeohyphomycosis are rare but most serious forms of disease. Cerebral phaeohyphomycosis generally manifest as brain abscess. C. bantiana is highly neurotropic hence frequently isolated from brain abscess. Early diagnosis, followed by aggressive combined surgical and medical management is necessary for a good outcome. ${ }^{1}$

\section{CASE}

A 55-year-old Indian male who was diabetic for the last four years came with complaints of slurred speech and weakness over left half of body. He took irregular anti-diabetic treatment and was poorly controlled on diet. He had become inattentive ten days back. He had headache and fever of one day duration only and became unconscious in due course of time. The chest XRay was normal. Laboratory investigations of blood revealed a hemoglobin level of $15.4 \mathrm{~g} / \mathrm{dl}$, white blood cells counts ranging between 14300$18900 /$ cumm. Renal function test, liver function test and serum electrolytes were within normal range. Blood culture was sterile. CT scan was done which revealed a large, irregular, peripheral ring-enhancing necrotic lesion in the right frontoparietal region causing significant mass effect and midline shift with perifocal oedema (Figure 1). He was operated upon and right frontoparietal craniotomy was done for decompression of space occupying lesion (SOL).

The necrotic material with pus-like caseous material was seen in thick-walled cavity which was removed and sent to both Microbiology departments. Microscopic examination of the $\mathrm{KOH}$ preparation revealed numerous septate and darkly pigmented fungal hyphae (Figure 2). Gram

Correspondence: Atul Aher, Department of Microbiology, Peoples College of Medical Science \& Research Centre, Bhanpur bypass Road, Bhopal 462037 M.P., India, Tel: +91-755-4296019 Email: atulaher@hotmail.com 
and Ziehl-Neelsen smears did not reveal any bacteria or acid fast structures. Sample was further cultured on Sabouroud dextrose agar (SDA) plain, SDA with gentamicin, SDA with actidione. The tubes were incubated at $35^{\circ} \mathrm{C}$ and $25^{\circ} \mathrm{C}$. After 72 hours of incubation, the tube showed colonies with an olive gray velvety appearance with a black undersurface. For identification, slide culture was done which showed dark walled septate hyphae with single celled oval conidia in long branched chains (Figure 3). Hyphae were septate and darkly pigmented with many conidia attached to the sides and lying free. Conidia were one-celled, pale brown, smooth-walled, and ellipsoid in shape. The conidiophores showed an acropetous type of branching. The isolate could be grown at $42^{\circ} \mathrm{C}$ and was also urease positive, features which differentiate $C$. bantiana from other morphologically similar saprophytic fungi.2 Patient was non-reactive for syphilis and HIV infection.

For the management of the case, insulin infusion was given along with intravenous conventional amphotericin B (1.5 mg/kg/day). During the follow-up there was no improvement in the clinical status of the patient. Therefore third CT scan was obtained and which showed decrease in size of lesion. However there was enlargement in mass effect as well as increase in edema. Despite the application of antifungal therapy the patient eventually expired two weeks after the onset of the disease.

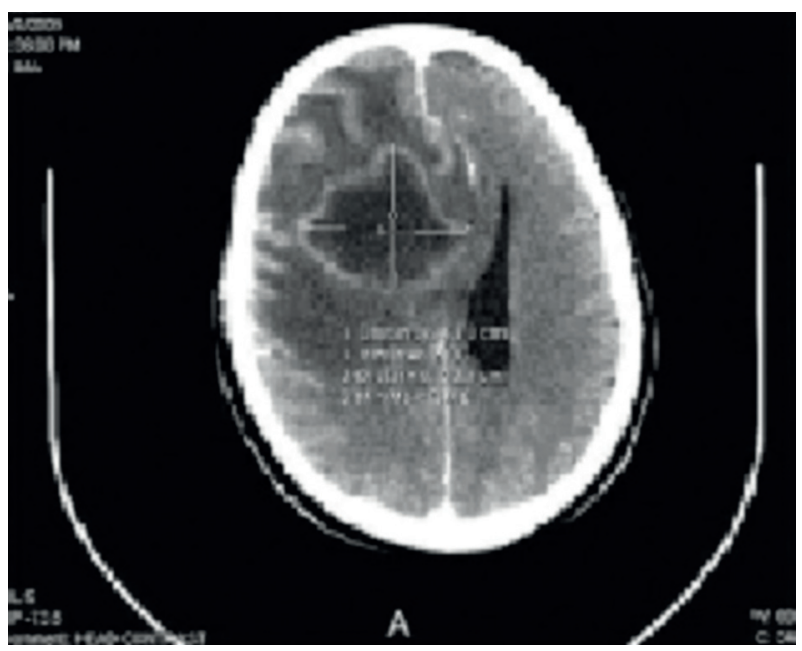

Figure 1. CT showing a large, irregular, peripheral ringenhancing necrotic lesion in the right frontoparietal region causing significant mass effect and midline shift with perifocal oedema

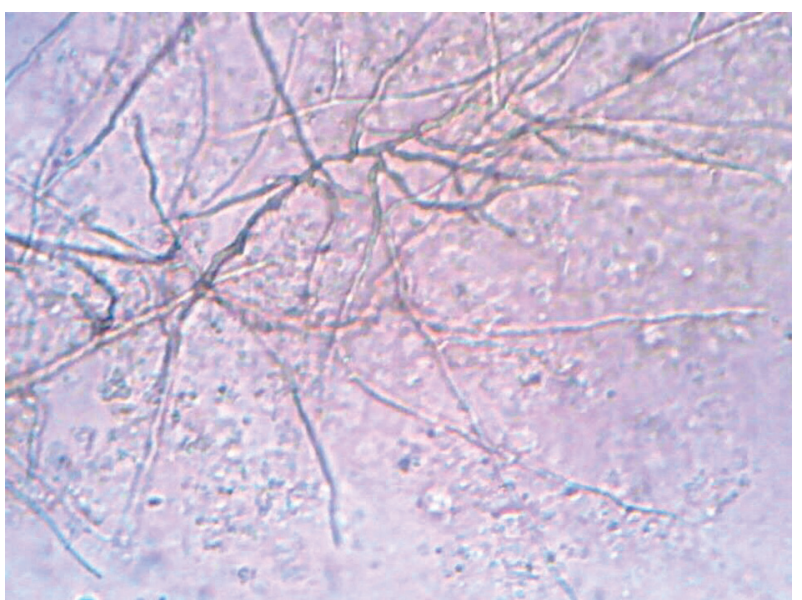

Figure 2. $10 \% \mathrm{KOH}$ mount of pus from brain abscess showing dark brown, septate branching hyphae (Magnification - 400X)

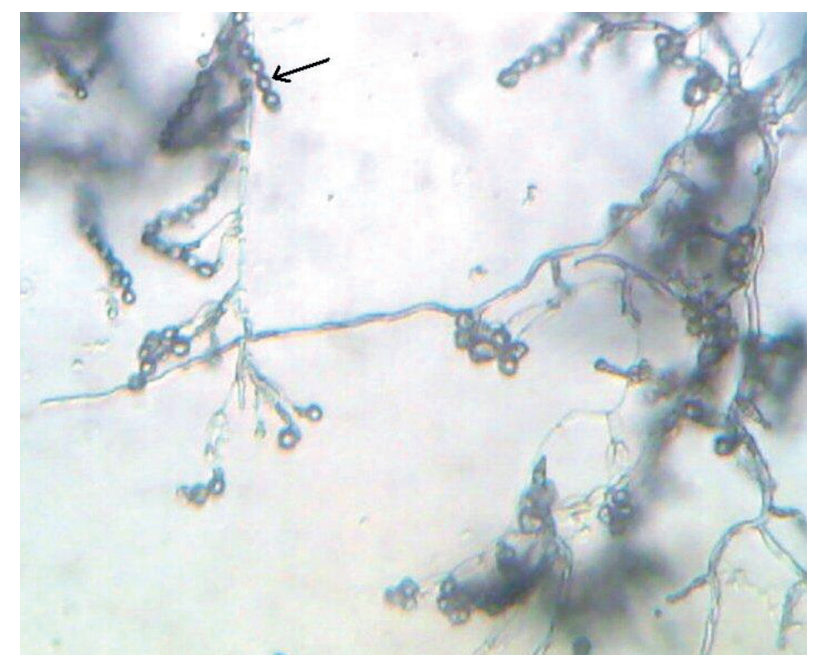

Figure 3. Slide culture showing dark walled septate hyphae with single celled oval conidia in long branched chains (arrow) compatible with Cladophialophora bantiana (Magnification - 400X)

\section{DISCUSSION}

Fungal infections of the central nervous system (CNS) were considered rare until the 1970s. This is no longer true in recent years due to widespread use of corticosteroids, cytotoxic drugs and antibiotics. Immunocompromised patients with underlying malignancy, organ transplantations and acquired immune deficiency syndrome are all candidates for acquiring fungal infections either in meninges or brain. A considerable number of cases of CNS fungal infections even in immunocompetent hosts have been reported. A vast array of fungi may cause infection in the CNS, but 
barring a few, most of them are anecdotal case reports. Cryptococcus neoformans, Candida albicans, Coccidioides immitis. Histoplasma capsulatum are common causes of fungal meningitis; Aspergillus spp., Candida spp., Zygomycetes and some of the melanized fungi are known to cause mass lesions in brain. Few fungi like $C$. neoformans, C. bantiana, Exophiala dermatitidis, Ramichloridium mackenzie, Ochroconis gallopava are considered as true neurotropic fungi. ${ }^{1}$

Phaeohyphomycoses (melanized fungi) encompass a diverse group of dematiaceous fungal infections characterized by pigmented hyphae in the tissues. CNS infections by melanized fungi have increasingly been reported in recent years. ${ }^{2-4}$ Primary cerebral infections are predominantly caused by Exophiala dermatitidis, Cladophialophora bantiana, Ramichloridium mackenzie under the order Chaetothyriales. Occasionally, Ochroconis gallopava is encountered. Secondary cerebral infections are usually an extension from chronic sinusitis and are due to grass-inhabiting species under the Genera Bipolaris, Dissitimurus, Exserohilum (order Pleosporales). C. bantiana, a neurotropic fungus, has rarely been isolated from sources other than living mammal tissue. Central nervous system infection due to $C$. bantiana is reported worldwide, though a general preference for warmer climate with high humidity is apparent. ${ }^{3,4}$ Amongst the cases of phaeophyphomycoses, $48 \%$ of the cases were reported to have been caused by $C$. bantiana. The mortality rate in these cases was $71 \%$. The predisposing factors for fungal infection in these patients were mostly glucocorticoid treatment, diabetes mellitus, lymphoma with neutropenia, eye trauma and intravenous drug abuse. ${ }^{5}$ In our case the patient was a diabetic which was the predisposing factor for the fungal infection. With the increase of diabetic patients worldwide, uncontrolled diabetes or diabetic ketoacidosis is an important predisposing factor for CNS mycoses. ${ }^{6,7}$

Fungal infection of the central nervous system (CNS) is a life-threatening disease. Most important determinant for cure is resectability of lesion. Antifungal therapy alone is not associated with improved survival. The current recommen- dation is a combination of total surgical excision followed by systemic antifungal therapy. ${ }^{5} \mathrm{Am}$ photericin $\mathrm{B}$, flucytosine, itraconazole have been used with varying success in $C$. bantiana brain abscess. The use of liposomal amphotericin B has been suggested as a way to increase the dose of amphotericin $B$ while reducing its toxic effects, particularly nephrotoxicity. In vitro data suggest that itraconazole, voriconazole, and amphotericin $B$ have activity against $C$. bantiana, with the azoles having lower MICs than amphotericin. ${ }^{8}$ A newer azole, voriconazole was found effective in various in vitro studies. It has good penetration in CSF and brain tissue in comparison to itraconazole which do not have good CSF penetration. Voraconazole acts by inhibiting ergosterol biosynthesis which is an integral component of fungal cell wall. ${ }^{9}$ However even voriconazole along with liposomal amphotericin B could not save the patient in some of the cases. ${ }^{10}$

\section{REFERENCES}

1. Chakrabarti A. Epidemiology of central nervous system mycoses. Neurol India 2007; 55:191-197.

2. Chandramuki A, Ramadevi MG, Shankar SK. Cerebral cladosporiosis: A neuropathological and microbiological study. Clin Neurol Neurosurg 1983; 85:245-253.

3. Huang WM, Fan YM, Li W, Yang WW. Brain abscess caused by Cladophialophora bantiana in China. J Med Microbiol 2011; 60 (Pt 12):1872-4.

4. Kantarcioglu AS, de Hoog GS. Infections of the central nervous system by melanized fungi: A review of cases presented between 1999 and 2004. Mycoses 2004; 47:4-13.

5. Revankar SG, Sutton DA, Rinaldi MG. Primary central nervous system phaeohyphomycosis: A review of 101 cases. Clin Infect Dis 2004; 38: 206-216

6. Chakrabarti A, Das A, Mandal J, et al. The rising trend of invasive zygomycosis in patients with uncontrolled diabetes mellitus. Med Mycol 2006; 44:335-342.

7. Pellacchia V, Terenzi V, Moricca LM, Buonaccorsi S, Indrizzi E, Fini G. Brain abscess mycotic and bacterial infection in a diabetic patient: Clinical report and review of literature. J Craniofac Surg 2006; 17:578-584.

8. Lakshmi V, Padmasri C, Umabala P, Sundaram C, Panigrahi M. Cerebral phaeohyphomycosis due to Cladophialophora bantiana. Indian J Med Microbiol 2008; 26:392-395.

9. Lyons MK, Blair JE, Leslie KO. Successful treatment with voriconazole of fungal cerebral abscess due to Cladophialophora bantiana. Clin Neurol Neurosurg 2005; 107:532-534.

10. Fica A, Diaz MC, Luppi M, et al. Unsuccessful treatment with voriconazole of a brain abscess due to Cladophialophora bantiana. Scand J Infect Dis 2003; 35:892-893. 